\title{
HASIL BELAJAR DAN KINERJA SISWA SMA PADA PEMBELAJARAN KONSEP PROTISTA MELALUI PENDEKATAN INQUIRI TERBIMBING
}

\author{
FATHUL ZANNAH \\ Tenaga Pengajar Pada Program Studi Pendidikan Guru Sekolah Dasar FKIP Universitas \\ Muhammadiyah Palangkaraya
}

\begin{abstract}
ABSTRAK
Kegiatan pembelajaran di SMAN 2 Banjarbaru sudah mengarah kepada kegiatan pengamatan namun belum optimal menerapkan pendekatan inkuiri terbimbing secara terperinci. Hal ini mengakibatkan kinerja siswa belum terasah, yang sebenarnya sangat diperlukan dalam pendidikan biologi. Penelitian ini bertujuan: menguji signifikansi hasil belajar siswa berupa produk antara kelas perlakuan dan kelas kontrol; menguji signifikansi hasil belajar siswa berupa proses antara kelas perlakuan dan kelas kontrol; mengukur kinerja siswa. Penelitian ini dirancang dengan kuasi eksperimen The Nonequivalent Control Group Design. Sampel penelitian ini adalah siswa kelas X5 dan kelas X4 sebagai kelas perlakuan dan kelas X1 sebagai kelas kontrol. Ada perbedaan rata-rata belajar produk kelas perlakuan dengan kelas kontrol dalam 3 kali pembelajaran $(29,5-28,21 ; 51,2-28,93 ; 70,2-27,14)$. Perbedaan ini signifikan berurut (Fo = 16,76; $P=0,0001$, $F o=43,60 ; P=0,0001$, $F o=140,47 ; P=0,0001$ ), ada perbedaan rata-rata belajar proses kelas perlakuan dengan kelas kontrol dalam 3 kali pembelajaran ( 53,8-30,36; 60-37,5; 72,131,43). Perbedaan ini signifikan berturut $(F o=88,77 ; P=0,0001$, Fo $=98,76 ; P=0,0001$, $F o=$ 245,92; $P=0,0001$, kinerja siswa, keterampilan perilaku berkarakter, keterampilan sosial dan penilaian psikomotor mengalami peningkatan.
\end{abstract}

Kata Kunci: Inkuiri Terbimbing, Hasil Belajar, Kinerja,

\section{ABSTRACT}

Learning activities in SMAN 2 Banjarbaru has led to the observation of activities, but not optimal guided inquiry approach in detail. This resulted in performance students have not been honed, which is indispensable in biology education. This study aims to: test the significance of student learning outcomes in the form of a product between treatment classes and control classes, test the significance of the process of student learning outcomes between treatment classes and control classes, measure student performance. The study was designed with a quasi-experimental The Nonequivalent Control Group Design. Sample of this study is class grade students X5 and X4 as a class treatment and X1 as a control classes. There are differences of the average of learning product treatment classes with control classes in 3 times learning (29.5 to $28.21 ; 51.2$ to $28.93 ; 70.2$ to 27.14 ). This difference was significant sequential (Fo $=16.76, \mathrm{P}=$ 0.0001 , $\mathrm{Fo}=43.60, \mathrm{P}=0.0001$, $\mathrm{Fo}=140.47, \mathrm{P}=0.0001$ ), there are differences in the average learning in the class of treatment with a class of learning control in 3 times learning (53.8 to $30.36 ; 60$ to $37.5: 72.1$ to 31.43). This difference was significant sequential $(F o=88.77, P=0.0001, F o=98.76, P=0.0001$, $F o=$ 245.92, $P=0.0001$, the performance of students, characterized by behavioral skills, social and psychomotor skills assessment has increased.

Keywords: Guide Inquiry, Learning Outcomes, Performance, 


\section{PENDAHULUAN}

Pendidikan merupakan sarana dalam mewujudkan sumber daya manusia yang berkualitas, oleh karena itu pemerintah harus selalu melakukan pembaharuan kurikulum secara berkala. Kurikulum terakhir yang diterapkan yaitu Kurikulum Tingkat Satuan Pendidikan atau KTSP yang menuntut agar proses pembelajaran berpusat kepada siswa (student centered) yang dapat terlihat dari perangkat pembelajaran. Perangkat pembelajaran yang sesuai dengan tuntutan KTSP memang tidak mudah dirancang, terlebih lagi dengan diberlakukannya Permendiknas No. 41 tahun 2007 tentang RPP yang menghendaki pengintegrasian nilai-nilai pendidikan budaya dan karakter bangsa melalui pembelajaran aktif. Oleh karena itu perlu adanya pembenahan dalam perancangan perangkat pembelajaran, salah satunya dalam pembelajaran biologi.

Pendidikan Biologi menekankan pada pemberian pengalaman secara langsung sehingga siswa perlu dibantu untuk mengembangkan sejumlah keterampilan proses supaya mereka mampu menjelajahi dan memahami alam sekitar (Ridwan, 2010). Oleh karena itu, perangkat pembelajaran yang dirancang diharapkan dapat menjadi wadah bagi terlaksananya tujuan yang sesuai dengan tuntutan kurikulum KTSP, tidak terkecuali pada konsep protista. Salah satu pendekatan yang dapat diterapkan dalam kegiatan pembelajaran yaitu pendekatan inkuiri terbimbing yang dilandasi oleh teori pembelajaran konstruktivis.

Berdasarkan hasil wawancara, pembelajaran konsep protista di SMAN 2 Banjarbaru sudah memberikan pengalaman secara langsung kepada siswa dengan kegiatan pengamatan menggunakan mikroskop. Namun kegiatan pengamatan yang dilakukan masih belum terorganisir sehingga terkesan hanya sekedar melakukan pengamatan semata. Selain itu dalam kegiatan pembelajarannya belum pernah menerapkan pendekatan inkuiri terbimbing secara terperinci sehingga keterampilan kinerja siswa masih belum terasah secara optimal.

Penelitian semacam ini perlu dikembangkan lebih lanjut pada konsep yang berbeda. Atas dasar ini maka dilakukan penelitian tentang hasil belajar, kinerja siswa SMA pada pembelajaran konsep protista melalui pendekatan inkuiri terbimbing. Masalah dalam penelitian ini dirumuskan sebagai berikut: Bagaimana hasil pembelajaran konsep protista melalui pendekatan inkuiri terbimbing terhadap hasil belajar dan kinerja siswa di SMA? Sehingga tujuan dalam penelitian ini adalah untuk (1) menguji signifikansi hasil belajar siswa berupa produk antara kelas perlakuan dan kelas control, (2) menguji signifikansi hasil belajar siswa berupa proses antara kelas perlakuan dan kelas control, (3) mendeskripsikan kinerja siswa kelas X SMAN 2 Banjarbaru dalam pembelajaran melalui pendekatan inkuiri terbimbing..

\section{KAJIAN PUSTAKA}

\section{Kinerja Siswa}

Menurut Borich (2005) hasil kinerja tidak dapat diukur dengan tes kognitif saja. Siswa, misalnya mungkin dapat membaca semua aturan tata bahasa tanpa ragu-ragu tetapi tidak mampu menulis tentang acara sederhana yang mereka alami. Mereka mungkin mengetahui struktur selular tanaman tetapi tidak dapat menggunakan mikroskop untuk melihat apa yang mereka 
ketahui, mereka mungkin antusias mengkomunikasikan pikiran mereka untuk menutup teman-teman tapi takut untuk membuat presentasi lisan ke kelas. Hasil kinerja yang memerlukan analisis, sintesa, dan pengambilan keputusan yang dapat dipercaya untuk memicu interaksi siswa dengan orang lain (teman sebaya dan orang dewasa) dan kesadaran dari siswa untuk belajar sendiri dari buku-buku.

\section{Pendekatan Inkuiri Terbimbing dalam Pembelajaran Biologi}

Pendekatan pembelajaran merupakan suatu gambaran umum mengenai kegiatan pembelajaran yang akan dilaksanakan. Inkuiri terbimbing merupakan salah satu pendekatan pembelajaran dimana guru dan siswa berpartisipasi dalam menentukan dan menyelidiki suatu masalah, menentukan cara, menyelidiki dan melakukan uji coba, serta mengevaluasi data mereka dan membuat kesimpulan (Schwarz, 2006).

\section{METODE PENELITIAN \\ Rancangan Penelitian}

Penelitian ini dilaksanakan dengan menggunakan rancangan kuasi eksperimen (quasi experiment) The Nonequivalent Control Group Design (Campbell \& Stanley, 1966) Penelitian deskriptif untuk mengukur kinerja siswa diadaptasi dari Borich (Borich, 2005). Kinerja siswa dengan menggunakan format pengamatan

1) kegiatan kolaboratif dan kelompok, 2) Penerapan hasil belajar oleh siswa melalui proyek atau demonstrasi, 3) Keterlibatan siswa dalam kinerja lisan, dan 4) penggunaan ketetapan kinerja.

\section{Populasi dan Sampel}

Populasi dalam penelitian ini adalah seluruh siswa Kelas X SMA Negeri 2 Banjarbaru yang berjumlah 240 orang. Sampel ditetapkan sebanyak 3 kelas, dua kelas perlakuan dan satu kelas kontrol. Sampel dalam penelitian ini adalah siswa kelas X4 yang berjumlah 26 orang dan siswa kelas $X 5$ yang berjumlah 28 orang sebagai kelas perlakuan, siswa kelas $\mathrm{X} 1$ yang berjumlah 28 orang sebagai kelas kontrol dimana sampel ditetapkan secara acak.

\section{Waktu dan Tempat Penelitian}

Penelitian ini dilakukan di SMA Negeri 2 Banjarbaru yang beralamat di Jalan Mentaos Banjarbaru. Penelitian dilaksanakan selama 3 minggu yaitu pada bulan November.

\section{Variabel Penelitian}

Variabel bebas dalam penelitian ini adalah pembelajaran pendekatan inkuiri terbimbing meliputi silabus, bahan ajar, RPP dan LKS, sedangkan variabel terikat adalah hasil belajar sesuai dengan tujuan penelitian nomor 1 dan nomor 2, keterampilan berpikir tingkat tinggi dan kinerja siswa sesuai dengan tujuan penelitian nomor 3 dan nomor 4. Variabel yang dikontrol dalam penelitian ini adalah silabus, soal, buku, kemampuan siswa dan guru.

\section{Instrumen Penelitian}

Instrumen penelitian ini meliputi Silabus, RPP, LKS, Kunci LKS, Lembar Penilaian, Kunci Lembar Penilaian, bahan ajar, dan lembar pengamatan efektifitas kegiatan pembelajaran (adaptasi dari Borich, 2005). Instrumen penelitian dilakukan validasi 
isi oleh Prof. Dr. Endang Susantini, M.Pd dan

Dr. H. Muhammad Zaini, M.Pd.

\section{Teknik Pengumpulan Data}

Teknik pengumpulan data ditentukan berdasarkan tujuan penelitian.

(1) Data hasil belajar produk pada konsep protista diperoleh dari tes awal dan tes akhir siswa pada kegiatan pembelajaran pendekatan inkuiri terbimbing.

(2) Data hasil belajar proses pada konsep protista diperoleh dari tes awal dan tes akhir siswa pada kegiatan pembelajaran pendekatan inkuiri terbimbing.

(3) Kinerja siswa diperoleh dari lembar pengamatan efektifitas pembelajaran yang diadaptasi dari Borich (2005).

\section{Teknik Analisis Data}

Analisis data terhadap hasil penelitian dijelaskan sebagai berikut:

(1) Hasil penelitian berupa data kuantitatif yaitu hasil belajar siswa berupa produk diperoleh dari nilai pre tes dan post tes dari kelas eksperimen dan kelas kontrol. Data yang diperoleh selanjutnya dianalisis dengan menggunakan teknik analisis kovarian, di mana skor rata-rata tes awal digunakan sebagai kovariannya.

(2) Hasil penelitian berupa data kuantitatif yaitu hasil belajar siswa berupa proses diperoleh dari nilai pre tes dan post tes dari kelas eksperimen dan kelas kontrol. Data yang diperoleh selanjutnya dianalisis dengan menggunakan teknik analisis kovarian, di mana skor rata-rata tes awal digunakan sebagai kovariannya.

(3) Data kinerja siswa di analisis secara deskriptif.

\section{HASIL PENELITIAN}

\section{Hasil Belajar Produk}

Rata-rata hasil belajar produk kelas perlakuan dan kelas kontrol disajikan pada Tabel 1.

Tabel 1 Rata-rata Hasil Belajar Produk

\begin{tabular}{|c|c|c|c|c|c|c|c|c|c|c|c|}
\hline \multicolumn{4}{|c|}{ Pertemuan I } & \multicolumn{3}{c|}{ Pertemuan II } & \multicolumn{4}{c|}{ Pertemuan III } \\
\hline \multicolumn{2}{|c|}{ Kontrol } & Perlakuan & \multicolumn{2}{c|}{ Kontrol } & Perlakuan & \multicolumn{2}{c|}{ Kontrol } & \multicolumn{2}{c|}{ Perlakuan } \\
\hline Pre & Post & Pre & Post & Pre & Post & Pre & Post & Pre & Post & Pre & Post \\
\hline 17,9 & 28,21 & 14 & 29,5 & 18,21 & 28,93 & 19 & 51,2 & 12,14 & 27,14 & 16,9 & 70.2 \\
\hline
\end{tabular}

Ringkasan data uji signifikansi hasil belajar siswa berupa produk disajikan pada Tabel 2

Tabel 2 Signifikansi Hasil Belajar Produk

\begin{tabular}{|c|l|c|l|l|c|l|l|}
\hline Pertemuan & Sumber & DB/DF & JK/SS & RK/MS & F-Rasio & Pr $>$ F & Keterangan \\
\hline \multirow{2}{*}{1} & Regresi & 2 & 0.85 & 0.424 & 16.76 & 0.0001 & Signifikan \\
& Residual & 79 & 2.00 & 0.025 & & & \\
& Total & 81 & 2.85 & & & & \\
\hline \multirow{2}{*}{2} & Regresi & 2 & 1.65 & 0.824 & 43.60 & 0.0001 & Signifikan \\
& Residual & 80 & 1.51 & 0.018 & & & \\
& Total & 82 & 3.16 & & & & \\
\hline \multirow{3}{*}{3} & Regresi & 2 & 4.04 & 2.020 & 140.47 & 0.0001 & Signifikan \\
& Residual & 79 & 1.13 & 0.014 & & & \\
& Total & 81 & 5.17 & & & & \\
\hline
\end{tabular}

Keterangan: R-kuadrat = 0,29, c.v. $=10,91$ (pertemuan I), R-kuadrat = 0,52, c.v = 8,44 (pertemuan II) R-kuadrat $=0,78, \mathrm{c} . \mathrm{v}=6,99$ (pertemuan III). 


\section{Hasil Belajar Proses}

Rata-rata hasil belajar proses kelas perlakuan dan kelas kontrol disajikan pada Tabel 3.

Tabel 3 Rata-rata Hasil Belajar Proses

\begin{tabular}{|c|c|c|c|c|c|c|c|c|c|c|c|}
\hline \multicolumn{12}{|c|}{ Pertemuan } \\
\hline \multicolumn{4}{|c|}{ I } & \multicolumn{4}{|c|}{ II } & \multicolumn{4}{|c|}{ III } \\
\hline \multicolumn{2}{|c|}{ Kontrol } & \multicolumn{2}{|c|}{ Perlakuan } & \multicolumn{2}{|c|}{ Kontrol } & \multicolumn{2}{|c|}{ Perlakuan } & \multicolumn{2}{|c|}{ Kontrol } & \multicolumn{2}{|c|}{ Perlakuan } \\
\hline Pre & Post & Pre & Post & Pre & Post & Pre & Post & Pre & Post & Pre & Post \\
\hline 17,5 & 30,36 & 32,8 & 53,8 & 20 & 37,5 & 24,1 & 60 & 13,21 & 31,43 & 21,9 & 72,1 \\
\hline
\end{tabular}

Ringkasan data uji signifikansi hasil belajar siswa berupa proses yang telah didapat disajikan pada Tabel 4.

Tabel 4 Signifikansi Hasil Belajar Proses

\begin{tabular}{|c|c|c|l|l|l|l|l|}
\hline Pertemuan & Sumber & DB/DF & JK/SS & RK/MS & F-Rasio & Pr>F & Keterangan \\
\hline \multirow{1}{*}{$\mathbf{2}$} & Regresi & 2 & 1.70 & 0.851 & 88.77 & 0.0001 & Signifikan \\
& Residual & 79 & 0.75 & 0.009 & & & \\
& Total & 81 & 2.46 & & & & \\
& Regresi & 2 & 1.05 & 0.526 & 98.76 & 0.0001 & Signifikan \\
& Residual & 79 & 0.42 & 0.005 & & & \\
& Total & 81 & 1.47 & & & & \\
\hline \multirow{2}{*}{} & Regresi & 2 & 2.89 & 1.446 & 245.92 & 0.0001 & Signifikan \\
& Residual & 79 & 0.46 & 0.005 & & & \\
& Total & 81 & 3.35 & & & & \\
\hline
\end{tabular}

Keterangan: R-kuadrat $=069$, c.v. $=5,90$ (pertemuan I), R-kuadrat $=0,71$, c.v = 4,22 (pertemuan II), R-kuadrat $=0,86, c . v=4,38$ (pertemuan III)

Ringkasan hasil lembar kegiatan siswa disajikan pada Tabel 5.

Tabel 5 Ringkasan Hasil Lembar Kerja Siswa

\begin{tabular}{|c|c|c|c|c|}
\hline \multirow{2}{*}{ Pertemuan } & \multicolumn{2}{|c|}{ Skor } & \multirow{2}{*}{ Kategori hasil } & \multirow{2}{*}{} \\
\cline { 2 - 4 } & Seluruh Kelompok & Rata-rata & & \\
\hline I & 610 & 61 & 61 & Sedang \\
\hline II & 795 & 79,5 & 79,5 & Baik \\
\hline III & 640 & 64 & 64 & Sedang \\
\hline
\end{tabular}

Keterangan : Baik : 76 - 100\%, Sedang : 56 - 75\%, Kurang : $40-55 \%$, Sangat kurang :<40\% 


\section{Kinerja Siswa Selama Kegiatan Pembelajaran}

\section{Kinerja Siswa}

\section{a) Aktivitas Kelompok Selama Pembelajaran}

Ringkasan aktivitas kelompok selama pembelajaran seperti pada Tabel 6 .

Tabel 6. Ringkasan Hasil Aktivitas Kelompok Selama Pembelajaran

\begin{tabular}{|c|c|c|c|c|c|c|c|}
\hline \multirow[t]{2}{*}{ No. } & \multirow[t]{2}{*}{ Jenis Perilaku } & \multicolumn{3}{|c|}{ Pertemuan } & \multirow[t]{2}{*}{$\Sigma$} & \multirow{2}{*}{$\begin{array}{l}\text { Rata- } \\
\text { rata }\end{array}$} & \multirow[t]{2}{*}{ Kategori } \\
\hline & & 1 & II & III & & & \\
\hline 1 & Interaksi Guru-Siswa & 3,82 & 5 & 5,64 & 4,82 & 14,46 & Sangat baik \\
\hline 2 & Interaksi Siswa-Siswa & 4,28 & 5,18 & 6,36 & 5,27 & 15,82 & Sangat baik \\
\hline 3 & $\begin{array}{l}\text { Identifikasi tugas terhadap } \\
\text { bahan pendukung }\end{array}$ & 3,27 & 4,82 & 6 & 4,69 & 14,09 & Sangat baik \\
\hline 4 & $\begin{array}{l}\text { Identifikasi peran masing- } \\
\text { masing siswa }\end{array}$ & 5,18 & 5,27 & 6,18 & 5,54 & 16,63 & Sangat baik \\
\hline
\end{tabular}

Keterangan:

0-1,9= kurang $\quad 2-2,9=$ cukup $\quad 3-3,9=$ baik $\quad 4-5=$ sangat baik $\quad$ (Ratumanan, 2003)

b) Ringkasan Hasil Pengamatan Kegiatan Proyek dan Demonstrasi

Ringkasan hasil pengamatan kegiatan proyek dan demonstrasi seperti Tabel 7.

Tabel 7 Ringkasan Hasil Pengamatan Kegiatan Proyek dan Demonstrasi Selama Proses Pembelajaran

\begin{tabular}{|l|l|c|c|c|c|c|c|}
\hline \multirow{2}{*}{ No. } & \multicolumn{1}{|c|}{ Jenis Perilaku } & \multicolumn{3}{|c|}{ Pertemuan } & $\Sigma$ & $\begin{array}{c}\text { Rata- } \\
\text { rata }\end{array}$ & Kategori \\
\cline { 3 - 5 } & & I & II & III & & 4,88 & Sangat baik \\
\hline 1 & Menulis tugas & 3,82 & 4,82 & 6 & 14,64 & 4,88 & Sangat baik \\
\hline
\end{tabular}

Keterangan:

0-1,9 = kurang $2-2,9=$ cukup $3-3,9=$ baik $4-5=$ sangat baik (Ratumanan, 2003)

\section{c). Ringkasan Hasil Pengamatan Kinerja Lisan}

Ringkasan hasil pengamatan kinerja lisan siswa disajikan pada Tabel 8.

Tabel 8 Ringkasan Hasil Pengamatan Kinerja Lisan dalam Kegiatan Pembelajaran

\begin{tabular}{|c|c|c|c|c|c|c|c|}
\hline \multirow[t]{2}{*}{ No. } & \multirow[t]{2}{*}{ Perilaku } & \multicolumn{3}{|c|}{ Pertemuan } & \multirow[t]{2}{*}{$\Sigma$} & \multirow[t]{2}{*}{ Rata-rata } & \multirow[t]{2}{*}{ Kategori } \\
\hline & & 1 & II & III & & & \\
\hline 1 & Kinerja Oral & 4,72 & 5,27 & 6,27 & 16,26 & 5,42 & Sangat baik \\
\hline 2 & Pertanyaan-Pertanyaan Lisan & 4,45 & 5,18 & 6,36 & 15,99 & 5,33 & Sangat baik \\
\hline 3 & $\begin{array}{l}\text { Membaca/mempresentasikan } \\
\text { tugas }\end{array}$ & 3,9 & 4,82 & 5,9 & 14,62 & 4,87 & Sangat baik \\
\hline 4 & $\begin{array}{l}\text { Mendiskusikan ide/materi yang } \\
\text { diajarkan }\end{array}$ & 4.9 & 5,36 & 6,45 & 16,71 & 5,57 & Sangat baik \\
\hline 5 & $\begin{array}{l}\text { Mengkritik/Menganalisis respon } \\
\text { dari siswa lain }\end{array}$ & 3,18 & 3,09 & 4,09 & 10,36 & 3,45 & Baik \\
\hline 6 & $\begin{array}{l}\text { Membaca teks } \\
\text { pembelajaran }\end{array}$ & 5,36 & 6,09 & 7,09 & 18,54 & 6,18 & Sangat baik \\
\hline 7 & $\begin{array}{l}\text { Memberi pendapat } \\
\text { informal/laporan }\end{array}$ & 4,54 & 4 & 5 & 13,54 & 4,51 & Sangat baik \\
\hline
\end{tabular}

Keterangan :

$0-1,9=$ kurang $2-2,9=$ cukup $\quad 3-3,9=$ baik $\quad 4-5=$ sangat baik (Ratumanan, 2003) 


\section{d). Ringkasan Hasil Penilaian Kinerja}

Ringkasan penilaian kinerja dalam pembelajaran disajikan pada Tabel 9.

Tabel 9 Ringkasan hasil Penilaian Kinerja dalam Kegiatan Pembelajaran

\begin{tabular}{|c|c|c|c|c|c|c|c|}
\hline \multirow[t]{2}{*}{ No } & \multirow[t]{2}{*}{ Jenis perilaku } & \multicolumn{3}{|c|}{ Pertemuan } & \multirow[t]{2}{*}{$\Sigma$} & \multirow{2}{*}{$\begin{array}{l}\text { Rata- } \\
\text { rata }\end{array}$} & \multirow[t]{2}{*}{ Kategori } \\
\hline & & $\mathrm{I}$ & II & III & & & \\
\hline 1 & Kriteria produk & 5,73 & 4,82 & 5,82 & 16,37 & 5,45 & Sangat baik \\
\hline 2 & Kriteria proses & 5,82 & 4,64 & 5,64 & 16,1 & 5,36 & Sangat baik \\
\hline 3 & $\begin{array}{l}\text { Menggabungkan instruksi dikelas } \\
\text { dengan konteks realistis }\end{array}$ & 5,27 & 3,36 & 4,36 & 12,99 & 4,33 & Sangat baik \\
\hline 4 & Integrasi Pengetahuan & 4,36 & 3,45 & 4,45 & 12,26 & 4,08 & Sangat baik \\
\hline 5 & $\begin{array}{l}\text { Melakukan hal-hal yang rutin } \\
\text { dengan menggunakan informasi } \\
\text { yang diperoleh }\end{array}$ & 3,45 & 3,36 & 4,36 & 11,17 & 3,72 & Baik \\
\hline 6 & $\begin{array}{l}\text { Standar yang kompeten didunia } \\
\text { nyata }\end{array}$ & 6,36 & 4,73 & 5,64 & 16,73 & 5,57 & Sangat baik \\
\hline 7 & $\begin{array}{l}\text { Mewakili kehidupan nyata bukan } \\
\text { buku kerja }\end{array}$ & 6,18 & 5,27 & 4,45 & 15,9 & 5,3 & Sangat baik \\
\hline
\end{tabular}

Keterangan:

$0-1,9=$ kurang $\quad 2-2,9=$ cukup $\quad 3-3,9=$ baik $\quad 4-5=$ sangat baik (Ratumanan, 2003)

\section{Keterampilan Sosial}

Ringkasan pengamatan terhadap keterampilan sosial siswa pada Tabel 10.

Tabel 10 Ringkasan Hasil Pengamatan Keterampilan Sosial

\begin{tabular}{|l|c|c|c|c|c|c|}
\hline \multirow{2}{*}{\multicolumn{1}{c|}{ Parameter }} & \multicolumn{9}{c|}{ Pertemuan } \\
\cline { 2 - 7 } & \multicolumn{2}{|c|}{ I } & \multicolumn{2}{c|}{ II } & \multicolumn{2}{c|}{ III } \\
\cline { 2 - 7 } & $\Sigma$ & Rata-rata & $\Sigma$ & Rata-rata & $\Sigma$ & Rata-rata \\
\hline Bertanya & 25 & 2,27 & 29 & 2,63 & 39 & 3,55 \\
Menyumbang ide/pendapat & 22 & 2 & 28 & 2,55 & 42 & 3,82 \\
Komunikasi & 28 & 2,55 & 28 & 2,55 & 41 & 3,73 \\
\hline
\end{tabular}

\section{Keterampilan Perilaku Berkarakter}

Ringkasan pengamatan keterampilan perilaku berkarakter pada Tabel 11.

Tabel 11 Ringkasan Hasil Pengamatan Keterampilan Perilaku Berkarakter

\begin{tabular}{|l|c|c|c|c|c|c|}
\hline \multirow{2}{*}{ Parameter } & \multicolumn{6}{c|}{ Pertemuan } \\
\cline { 2 - 7 } & \multicolumn{2}{|c|}{ I } & \multicolumn{2}{c|}{ II } & \multicolumn{2}{c|}{ III } \\
\cline { 2 - 7 } & $\Sigma$ & Rata-rata & $\Sigma$ & Rata-rata & $\Sigma$ & Rata-rata \\
\hline Ketelitian & 18 & 1,64 & 25 & 2,27 & 39 & 3,55 \\
Tanggung jawab & 29 & 2,64 & 33 & 3 & 40 & 3,63 \\
Bekerja sama & 28 & 2,55 & 29 & 2,63 & 39 & 3,35 \\
Menghargai pendapat teman & 22 & 2 & 28 & 2,55 & 40 & 3,63 \\
\hline
\end{tabular}




\section{Penilaian Psikomotor}

Ringkasan hasil penilaian psikomotor siswa disajikan dilihat pada Tabel 12.

Tabel 12 Ringkasan Hasil Penilaian Psikomotor

\begin{tabular}{|c|c|c|c|c|c|c|}
\hline \multicolumn{2}{|c|}{ Kelompok } & \multicolumn{3}{|c|}{ Pertemuan } & \multirow[t]{2}{*}{ Rata-rata } & \multirow[t]{2}{*}{ Kategori } \\
\hline & & $\mathrm{I}$ & II & IIII & & \\
\hline \multirow{5}{*}{ Kelas X4 } & 1 & 69 & 84 & 95 & 82,67 & Baik \\
\hline & 2 & 70 & 86 & 92 & 82,67 & Baik \\
\hline & 3 & 73 & 87 & 94 & 84,67 & Baik \\
\hline & 4 & 68 & 82 & 97 & 82,33 & Baik \\
\hline & 5 & 73 & 89 & 93 & 85 & Baik \\
\hline \multirow{5}{*}{ Kelas X5 } & 1 & 75 & 82 & 95 & 84 & Baik \\
\hline & 2 & 73 & 82 & 96 & 83,67 & Baik \\
\hline & 3 & 73 & 82 & 96 & 83,67 & Baik \\
\hline & 4 & 72 & 84 & 93 & 83 & Baik \\
\hline & 5 & 70 & 85 & 94 & 83 & Baik \\
\hline
\end{tabular}

Keterangan:

$\begin{array}{lll}\text { Baik } & : 76-100 \% & \text { Sedang }: 56-75 \% \\ \text { Kurang } & : 40-55 \% & \text { Sangat kurang }:<40 \%\end{array}$

\section{PEMBAHASAN}

\section{Hasil Belajar Produk}

Pembelajaran menggunakan pendekatan inkuiri terbimbing dijumpai perubahan hasil belajar produk, dan perubahan ini signifikan. Hasil penelitian Sulistina (2009) pada prinsipnya telah mampu meningkatkan hasil belajar kimia siswa, selain itu pembelajaran inkuiri yang diterapkan pada mata pelajaran IPA cukup efektif dan efisien dalam meningkatkan kualitas hasil belajar siswa secara kontinyu (Mulyati, 2009) dan siswa secara keseluruhan mengalami peningkatan pemahaman konsep yang signifikan (Sopamena, 2009).

Hasil penelitian ini pada prinsipnya telah menemukan keefektifan model-model pembelajaran yang tergolong konstruktivis maupun dalam pembelajaran yang dikombinasikan dengan model pembelajaran kooperatif. Kegiatan pembelajaran yang dilaksanakan dengan setting kooperatif dimaksudkan agar siswa dapat saling membantu dalam menyelesaikan suatu permasalahan sehingga siswa lebih mudah belajar dan dapat mengoptimalkan pencapaian hasil belajar. Temuan ini sejalan dengan penelitian-penelitian yang telah dilaporkan sebelumnya (Dwindiasih, 2011; Yulinda, 2011). Hasil penelitian melaporkan kalau pendekatan lingkungan yang dikolaborasikan dengan pendekatan kooperatif berpengaruh positif terhadap hasil belajar pada konsep keanekaragaman hayati (Dwindiasih, 2011) dan proses problem solving dengan setting kooperatif juga berpengaruh positif terhadap hasil belajar berupa produk pada konsep jenis dan daur ulang limbah (Yulinda, 2011).

\section{Hasil Belajar Proses}

Pembelajaran menggunakan pendekatan inkuiri terbimbing dijumpai perubahan hasil belajar proses, dan perubahan ini signifikan. Hasil penelitian ini sejalan dengan penelitian-penelitian yang pernah dilaporkan (Solihat, 2011; Jalaludin, 2009). Berdasarkan hasil penelitian, terjadi 
peningkatan yang signifikan terhadap keterampilan proses sains siswa pada pembelajaran dengan menggunakan model pembelajaran inkuiri terbimbing dibandingkan dengan model konvensional (Solihat, 2011). Selain itu perpaduan pembelajaran inkuiri terbimbing dengan model pembelajaran berbasis masalah juga mampu meningkatkan kegiatan proses siswa berupa kecakapan mendesain penyelidikan (Jalaludin, 2009). Hasil penelitian ini pada prinsipnya telah menemukan keefektifan model-model pembelajaran yang tergolong konstruktivis.

Hasil Lembar Kerja Siswa berupa pengetahuan (produk) tergolong sedang, hasil ini sejalan dengan temuan yang pernah dilaporkan bahwa proses belajar yang diukur melalui LKS dan dianalisis secara deskriptif tergolong sedang (Yulinda, 2011). Selain itu hasil lembar kerja siswa berupa proses juga tergolong sedang, hasil ini tidak sejalan dengan temuan yang pernah dilaporkan bahwa proses belajar yang dilaksanakan berdasarkan pembelajaran konstruktivis dan diukur melalui LKS serta dianalisis secara deskriptif tergolong baik (Dwindiasih, 2011). Lembar kerja siswa memberikan kesempatan bagi siswa dalam bekerja sama serta berperan aktif dalam kegiatan pembelajaran.

\section{Kinerja Siswa Selama Kegiatan Pembelajaran}

Berdasarkan hasil pengukuran kinerja siswa yang berjumlah 20 buah parameter, hanya 4 buah parameter yang mengalami penurunan yaitu kriteria proses, menggabungkan instruksi di kelas dengan konteks realitas, standar yang kompeten di dunia nyata dan mewakili kehidupan nyata bukan buku kerja. Jadi kinerja siswa dalam pembelajaran sudah menunjukkan peningkatan. Hasil penelitian ini sejalan dengan penelitian sebelumnya (Viyanti, 2009; Windarwati, 2010; Faizah, 2009). Penilaian kinerja pada praktikum fluida statis (Viyanti, 2009) dan praktikum cahaya (Windarwati, 2010) berbasis inkuiri lebih tinggi secara signifikan dibandingkan menggunakan paper and pencil test dan implementasi model pembelajaran inkuiri juga mampu meningkatkan kinerja siswa dalam pembelajaran IPA kelas V (Faizah, 2009).

Keterampilan sosial siswa juga telah mengalami peningkatan pada saat proses pembelajaran, pengamatan yang dilakukan terhadap ketreampilan sosial siswa dilakukan terhadap tiga parameter pengamatan, yaitu bertanya, menyumbang ide atau pendapat dan komunikasi. Hal ini dapat terukur karena pembelajaran dilakukan secara berkelompok sehingga terjadi interaksi antara sesama anggota kelompok yang pada akhirnya memunculkan berbagai pertanyaan atau pendapat dalam penyelesaian suatu permasalahan yang sedang didiskusikan.

Keterampilan perilaku berkarakter juga mengalami peningkatan, pengamatan terhadap keterampilan perilaku berkarakter dilakukan terhadap 4 parameter yaitu ketelitian, tanggung jawab, bekerja sama dan menghargai pendapat teman. Dari keempat parameter pengamatan semuanya mengalami peningkatan, hal ini disebabkan karena pada pembelajaran dengan menggunakan pendekatan inkuiri terbimbing akan melatih keterampilan perilaku berkarakter siswa. Pembelajaran berbasis inkuiri menerapkan kegiatan penyelidikan (Nur dan Wikandari, 2000). Oleh karena itu, dalam kegiatan penyelidikan 
dapat melatih keterampilan siswa dalam segi ketelitian, tanggung jawab, bekerja sama dan menghargai pendapat teman.

Kemampuan psikomotor siswa juga sudah baik, karena hampir semua kelompok dapat menggunakan mikroskop sesuai dengan rincian tugas kinerja yang telah disusun oleh guru. Sikap melaksanakan kegiatan ini didasari oleh adanya kepentingan untuk menyelesaikan Lembar Kerja Siswa. Dengan demikian dapat dikatakan bahwa keterampilan psikomotor siswa menggunakan mikroskop telah terasah dengan mengikuti kegiatan pembelajaran yang berbasis inkuiri. Hal ini sejalan dengan pendapat Ibrahim (2000), di mana dalam pembelajaran yang berbasis inkuiri yang mengikuti metode sains, siswa belajar menjadi seorang ilmuwan. Siswa tidak hanya belajar tentang konsep atau fakta, tetapi juga proses dan sikap.

\section{KESIMPULAN}

Berdasarkan hasil penelitian dan pembahasan tentang hasil belajar siswa SMA pada pembelajaran konsep protista melalui pendekatan inkuiri terbimbing dapat disimpulkan:

1. Pembelajaran menggunakan pendekatan inkuiri terbimbing berpengaruh terhadap hasil belajar produk.

2. Pembelajaran menggunakan pendekatan inkuiri terbimbing berpengaruh terhadap hasil belajar proses.

3. Hasil kinerja siswa selama kegiatan pembelajaran sudah menunjukkan peningkatan. Selain itu keterampilan sosial, keterampilan perilaku berkarakter dan psikomotor juga mengalami peningkatan.

\section{DAFTAR PUSTAKA}

Arikunto, Suharsimi. 1998. Prosedur Penelitian Suatu Pendekatan Praktek. Jakarta: Rineka Cipta.

Borich, Gary, D. 2005. Observation Skills of Effective Teaching. New York: Merril Publishing Company.

Champbell, Donald T \& Julian, Stanley, 1996. Experimental and Quasi Experimental Design for Research On Teaching. Dalam N.L. Gage (penyunting). Handbook of Research On Teaching.A Project of the American Educational Research Association. Chicago: Departemen of The National Education Association.

Dwindiasih, Wahyuli. 2011. Pemahaman Konsep Keanekaragaman Hayati dan Etika Lingkungan Siswa SMAN 3 Banjarbaru melalui Pendekatan Lingkungan. Tesis. Pascasarjana Pendidikan Biologi. Banjarmasin. Tidak Dipublikasikan.

Faizah, Kurniyatul. 2008. Implementasi Model Pembelajaran Inquiry Sebagai Upaya Peningkatan Kinerja Siswa Dalam Pembelajaran IPA $\mathrm{Di}$ Madrasah Ibtidaiyah. Tesis. Program Pascasarjana. Universitas Negeri Yogyakarta.

Ibrahim, Muslimin, Fida Rachmadiarti, Mohamad Nur, Ismono. 2000. Pembelajaran Kooperatif. Surabaya: University Press.

Jalaludin, Dudung. 2009. Penggunaan Model Pembelajaran Berbasis Masalah Dengan Pendekatan Inkuiri Terbimbing Untuk Meningkatkan Penguasaan Konsep Listrik Dinamis Dan Kecakapan Ilmiah Siswa SMA. Tesis. Program Pascasarjana. Universitas Pendidikan Indonesia.

Malik, Adam. 2010. Model Pembelajaran Inkuiri Dengan Menggunakan Virtual Laboratory Dan Real Laboratory Untuk Meningkatkan Penguasaan Konsep Dan Keterampilan Berpikir Kritis Siswa SMA Pada Topik Listrik Dinamis. Tesis. Program 
Pascasarjana. Universitas Pendidikan Indonesia.

Mulyati. 2009. Efektivitas Hasil Belajar Pembelajaran Inkuiri Dibandingkan Pembelajaran Konvensional Kuasi Eksperimen Pada Mata Pelajaran Ipa Di Kelas V Sdn Kramatwatu di Kecamatan Kramatwatu Kabupten Serang Tahun Pelajaran 2008/2009. Tesis. Program Pascasarjana. Universitas Pendidikan Indonesia.

Nur, Mohammad \& Wikandari, P.R. 2000. Pengajaran Berpusat kepada Siswa dan Pendekatan Konstruktivis dalam Pengajaran. Surabaya: Pusat Studi Matematika dan IPA Sekolah. Universitas Negeri Surabaya.

Ratumanan, T.G \& Laurens, T. 2003. Evaluasi Hasil Belajar yang Relevan dengan Kurikulum Berbasis Kompetensi. Surabaya : Unesa Universitas Press.

Schwarz, Christina V dan Yovita N. Gwekwerere. 2006. Using a Guided Inquiry and Modeling Instructional Framework (EIMA) to Support Preservice K-8 Science Teaching. Michigan: Michigan State University.

Solihat. 2011. Penerapan Model Pembelajaran Inkuiri Terbimbing Pada Materi Perpindahan Energi Panas Untukmeningkatkan Penguasaan Konsep Keterampilan Proses Sains Dan Sikap Ilmiah Siswa SD. Tesis. Program Pascasarjana. Universitas Pendidikan Indonesia.

Sopamena, octavina. 2009. Model Pembelajaran Inkuiri Terbimbing Untuk Meningkatkan Pemahaman Konsep Dan Keterampilan Proses Sains Siswa Smk Pada Konsep Hasil Kali Kelarutan. Tesis. Program Pascasarjana. Universitas Pendidikan Indonesia.

Sulistina, oktavia. 2009. Keefektifan Penggunaan Metoda Pembelajaran Inkuiri Terbuka dan Inkuiri Terbimbing dalam Meningkatkan Proses Pembelajaran dan Hasil Belajar
Kimia Siswa SMA Laboratorium Malang Kelas $X$. Tesis. Program Pascasarjana. Universitas Pendidikan Indonesia.

Suparman, ade. 2011. Efektivitas model pembelajaran inkuiri dengan memanfaatkan multimedia interaktif berbasis komputer untuk meningkatkan keterampilan berpikir siswa : studi eksperimen pada mata pelajaran kimia untuk siswa sma di kota serang. Tesis. Program Pascasarjana. Universitas Pendidikan Indonesia.

Sutrisno, Joko. 2010. Menggunakan Keterampilan Berpikir untuk Meningkatkan Mutu Pembelajaran. (http://www.erlangga.co.id/index.php?opti on=com content\&task=view\&id=364\&lte mid=405). Di akses tanggal 25 Agustus 2011.

Viyanti. 2009. Penggunaan Asesmen Kinerja Pada Praktikum Fluida Berbasis Inkuiri Untuk Meningkatkan Keterampilan Generik Dan Penguasaan Konsep Siswa SMA. Tesis. Program Pascasarjana. Universitas Pendidikan Indonesia.

Windarwati, Retno. 2010. Penerapan Asesmen Kinerja Pada Pembelajaran Inkuiri Berbasis Laboratorium Untuk Meningkatkan Keterampilan Proses Sains Dan Penguasaan Konsep Materi Cahaya Siswa SMP. Tesis. Program Pascasarjana. Universitas Pendidikan Indonesia.

Yulinda, Ratna. 2011. Hasil Belajar, Kinerja, dan Keterampilan Berpikir Tingkat Tinggi Siswa SMA pada Pembelajaran Konsep Jenis dan Daur Ulang Limbah melalui Proses-Proses Problem Solving. Tesis. Pascasarjana Pendidikan Biologi. Banjarmasin. Tidak Dipublikasikan. 